\title{
Fighting transnational corruption
}

\author{
by Joseph Masè
}

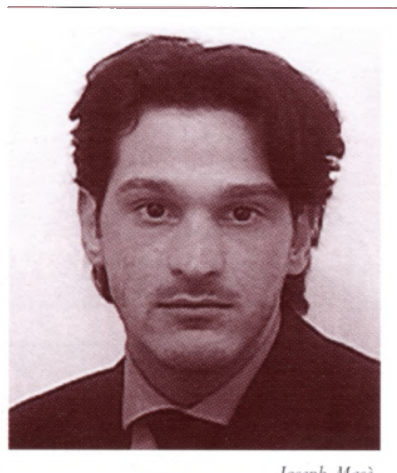

Joseph. Masè

International corruption in business transactions is viewed differently from national corruption. Joseph Masè discusses the reasons for this and the measures that need to be taken, by Central and Eastern Europe and CIS in particular, to combat international corruption.

$\mathrm{B}$ ribery is a widespread phenomenon in international business transactions, raising serious moral and political concern, undermining democracy, retarding development and distorting international competitive conditions. The fight against corruption in international business transactions should involve all countries.

While most countries are more or less seriously engaged in fighting national corruption, so far there has been very little interest in combating international corruption. National corruption differs from international corruption in that the first involves only people belonging to the same jurisdiction, while the second takes place outside the border of a single state and has a transnational range. In cases of international corruption, the corrupted is normally a public official. By 'foreign public official' one usually means:

- any person holding a legislative, administrative or judicial office of a foreign country, whether appointed or elected;

- any person exercising a public function for a foreign country, including for a public enterprise; and

- any official or agent of a public international organisation.

\section{DUAL STANDARDS}

The excuse for this different attitude is that the corruption of foreign officials is seen positively, in commercial competition, as something favouring the economic interest of the country by helping the export business or general business deals of national enterprises abroad. This is why some states, under the heading of intermediary commission, even allow the deduction from tax of bribes paid to foreign officials. This happens at the same time as they are seriously fighting corruption within their own countries.

The different standards of behaviour seem to be based on the assumption that there is no link between the two types of corruption and therefore it is possible to turn off the taps of bribery on the inside while leaving them to run freely outwards. Nothing could be more wrong. Countries which are determined to fight bribery within their national frontiers risk having their efforts thwarted if they do not take measures to combat international corruption. This is because the trend to a globalised economy makes the movement of capital more and more easy, but it is more difficult to follow their tracks along the international money trails.

Since 1977 there has existed in the US a specific law aimed at fighting international corruption: the Foreign Corrupt Practices Act 1977 (FCPA). This Act makes the bribery of foreign officials on behalf of American enterprises similar to the crime of corruption taking place on national territory. The FCPA does not limit its sanctions to international corruption carried out by American enterprises, but also extends them to companies generated by or affiliated to American enterprises, even though they fall under the juriscliction of another country. No other country has such a law.

As transnational corruption takes on the form of international crime, national legal instruments are inadequate to combat it. Therefore international organisations play a fundamental role in confronting this phenomenon, the suppression of which requires full co-operation among criminal justice agencies.

\section{ICC REPORT}

The International Chamber of Commerce (ICC) is among the organisations that first realised the importance of intergovernmental co-operation in combating international corruption. In 1977, the ICC issued a report on extortion and bribery in business transactions. This broke new ground in calling for complementary and mutually supportive action by governments, intergovernmental agencies, and the business community to combat extortion and bribery in international trade. This report aroused interest in several international organisations such as the Organisation for Economic Cooperation and Development (OECD) and the UN. Moreover, corporations in a number of countries were prompted to establish or strengthen their internal rules of fair practices, taking as a model the rules of conduct for enterprises set out in pt. 3 of the 1977 report.

In 1994 the ICC set up an ad hoc committec to review its 1977 report. On 26 March 1996 the executive board adopted the report entitled Extortion and Bribery in International Business Transactions. This document confirms the basic approach recommended initially, i.e. the need for action by international 
organisations, governments and enterprises, nationally and internationally, to meet the challenging goal of greater transparency in international trade. ICC, as the leading world business organisation, has, as a principal purpose, the stimulation of action by enterprises and business organisations in support of self-regulation as an important factor in effectively combating corruption and bribery.

For more than two decades the UN has been concerned with the problem of corruption. On 12 December 1996 the General Assembly adopted a resolution regarding the implementation of an international code of conduct for public officials. Among the most relevant instruments suggested are:

- the establishment of specialised anti-corruption bodies;

- guidelines for the performance of duties by public officials;

- the creation or the strengthening of the existing independent auditing institutions or bodies that vet public expenditures;

- measures that oblige public officials to disclose assets, liabilities and copies of their income tax returns;

- the development of transparency in the management of public funds and in the decision-making process.

By resolution 51/191 of 16 December 1996 on Corruption and Bribery in International Commercial Transactions, the General Assembly invites member states to make corruption and bribery of forcign public officials a criminal offence. States should review their legislation and establish that offence or pursuc effective enforcement of existing laws. The declaration also encourages states to adopt legislative and regulatory measures to make it impossible for corporate entities or individuals to obtain tax benefits or deductions for payments outside their countries that would constitute bribes or other inappropriate payments to foreign public officials. The General Assembly recommends that states, in accordance with their legal system, include in their legislation provisions for corporate criminal liability as a measure to enhance accountability of corporate entities and allow more effective enforcement of other legislative and regulatory measures against corruption. Finally, it invites states to adopt legislation that will allow the seizure and forfeiture of assets that are the fruits of corruption and bribery. Such assets may be used to provide the means for restitution for victims of corruption and to finance law enforcement investigations aimed at preventing and controlling corruption.

In December 1997 the ministers of the 29 OECD countries signed the Convention on Combating Bribery of Foreign Public Officials in International Business Transactions (The Czech Republic, Hungary and Poland are among the OECD members). The other five countries who have decided to sign the agreement are Argentina, Chile, Brazil, Bulgaria and Slovakia.

\section{INTERNATIONAL CO-OPERATION}

National legal instruments are not able efficiently to combat the phenomenon of international crime. An effective campaign against corruption in international trade may be undertaken only by means of the internationalisation of legal instruments. Therefore the authorities of the countries of Central and Eastern Europe should improve the efficiency and effectiveness of international cooperation by promoting bilateral and multilateral agreements, encouraging co-operation between criminal justice agencies and other authorities, and implementing the recommendations of international organisations.
The OECD will monitor implementation of the accord and whether member countries act to prosecute offending companies. The convention will make the corruption of foreign officials by companies to win contracts a criminal offence for companies in the 29 OECD countries and in the other five that signed it. The agreement covers payments to parliamentarians and to state-owned enterprises. OECD members reached only a partial solution on bribery of political party officials. For the moment the convention includes only indirect corruption of political parties, for instance, a bribe to a foreign official who wants the money to go to a particular political party.

\section{o $n$ the internet}

hHtp://www.icc.wbo.org

The International Chamber of Commerce site at the above address contains additional information on the ICC's aims and objectives and a variety of links to other useful sites.

If at least five of the ten largest OECD economies, representing at least $60 \%$ of total exports by OECD countries, ratify the agreement during 1998 , it will immediately come into force. If after 31 December 1998, the convention has not come into force, it will come into effect at the beginning of 1999, as long as two countries have ratified it.

\section{TI INTEGRITY PACT}

Transparency International (TI) is a non-governmental organisation, incorporated in 1993 as a non-profit organisation under German law. It is supported by a growing number of national chapters in over 40 countries. TI is apolitical, does not represent any particular sector or system and its mission is to curb corruption in international business transactions. TI is ready to work with all who share its objectives which are:

(1) to curb corruption through international and national coalitions encouraging governments to establish and implement effective laws, policies and anti-corruption programmes;

(2) to strengthen public support and understanding for anticorruption programmes and enhance public transparency and accountability in international business transactions and in the administration of public procurement;

(3) to encourage all parties to international business transactions to operate at the highest levels of integrity, guided in particular by TI's standards of conduct.

The investigations carried out by this organisation concern corruption in international trade, a phenomenon which, along with the globalisation of commercial and, more generally, economic activities, has itself reached a global dimension.

TI has expounded an integrity pact which intends to accomplish two objectives:

(1) to enable companies to abstain from bribery by providing assurances to them that their competitors will also refrain from it, and government procurement agencies will undertake to prevent any form of corruption, including extortion and to follow transparent procedures;

(2) to enable governments to reduce the high cost and the distorting impact of corruption on public procurements. 
The TI integrity pact would function as follows: a government, when inviting contractors or suppliers of goods and services to tender for a specific contract, informs the potential bidders that their tender offer must contain a commitment not to offer or pay any bribes in connection with the contract. The government for its part will commit itself to preventing extortion and the acceptance of bribes by its officials, and to follow transparent procurement rules.

\section{CENTRAL AND EASTERN EUROPE}

Moving towards a regional level, attention must be focused on the developments made in this field by the authorities of the Central and Eastern European states and the CIS. These countries, moving towards a market economy, are exposed to the problems that this transition produces in terms of corruption. The rapid economic, political and social changes offer new opportunities not only for economic development, but also for unfair enrichment due to the corruption of public officials.

During the communist period, obtaining products through bribery was socially accepted as a way of life. For many individuals, the giving and the accepting of bribes was an indication that they were enterprising, self-sufficient and doing well. Corruption was deemed to be necessary. After 1989, as a consumer market emerged and products became more widely available, a new kind of corruption emerged out of the legal systems which were not prepared for change. A gigantic process of property redistribution created shady links between political power and the new financial system. The tolerance of corruption was justified on the grounds that it helped the compensation of inadequate regulations.

Political instability, the liberalisation of international trade and the privatisation processes could be sources generating larger scales of corruption. The awareness of the authorities of the Eastern bloc about the dangers posed by corruption is confirmed by the intensive and dynamic legislative activities. It is essential that these governments understand that it is necessary to combat not only national but also international corruption.

Research recently conducted by Transcrime - a research group on transnational crime at the School of Law, University of Trento, Italy - identified the major trends in Central and Eastern Europe regarding anti-corruption strategies. The mechanisms most frequently adopted in this area are:

- the promulgation of special legislation and programmes fighting corruption (Bulgaria, Poland, Rumania, Russia, etc.);

- the establishment of independent authorities in order to coordinate the national activities for more effective actions against corruption (Hungary, Russia, Ukraine);

- the obligation for members of parliament and senior officials to report their assets and holdings to special commissions (Estonia, Poland, Rumania, Ukraine);

- the limitation in business of persons performing public functions;

- increasing the responsibility of public officials;

- the adoption of codes of conduct regulating the activity of public officials and those in professions exposed to corruption.

\section{PENAL MEASURES}

The enactment of specific anti-corruption legislation was the first step made by several countries in the fight against corruption.

\section{Poland}

Since 1992 the Polish authorities have been seriously fighting corruption. First the Act on Limitation in Business of Persons performing Public Functions was enacted. In 1992-93 the Act Suppressing Unfair Competition and the Public Procurement Act came into force with the aim of preventing corruption. In 1995 a set of Police Acts that introduced new methods of investigating corruption were approved. Finally, on 26 June 1997, the new anti-corruption law was approved. It obligates public officials to note gifts received in a public register and forbids them to hold any function in private companies. The corruption of foreign officials is not criminalised.

\section{Slovenia}

The Slovenian Government has taken the issue of corruption very seriously. Criminal acts of corruption, in the strict sense of bribery in commercial enterprises, are sanctioned in art. 247 and 248 of the criminal code, while the corruption of public officials is regulated in art. 257 and 268. New legislative provisions have been enacted or are in the process of being enacted, the innovative issues providing a wider definition of corruption, including the bribery of foreign officials.

\section{Estonia}

In Estonia specific anti-corruption legislation was enacted in 1995. This law provides a definition of corruption and lists the holders of public offices who might be held responsible for bribery. The anti-corruption legislation also offers new investigative measures.

\section{FOREIGN OFFICIALS}

The corruption of foreign officials is seen positively, in commercial competition, as something favouring the economic interest of the country by helping the export business or general business deals of national enterprises abroad. This is why some states, under the heading of intermediary commission, even allow the deduction from tax of bribes paid to foreign officials. This happens at the same time as they are seriously fighting corruption within their own countries.

\section{Hungary}

Corruption is regulated by art. 250-255 of the Hungarian Criminal Code. The provisions also include a definition of economic bribery. Moreover the specific Act on Obtaining Goods and Services at the Expense of Public Sources should be a valid instrument in the prevention of bribery.

\section{Czech Republic}

The Czech Government reformed the code of criminal procedure, the criminal code and the police law in order to harmonise these laws as much as possible with the European standards. The Czech Republic has a wide definition of corruption; in fact, the notion of 'public figure' includes not only those who belong to governmental, legislative and judicial structures but also cultural, social and other activities.

\section{Ukraine}

Ukraine has a special law relating to the fight against corruption. However this law of 5 October 1995 does not always appear efficient in that it forbids the acceptance of gifts and awards by members of parliament except for teaching, research and other creative work. These exceptions allow the offering of quite costly 'consulting'. 


\section{Russian Federation}

The Government of the Russian Federation has strengthened the legislative bases for the prevention of corruption through the drafting of statutes such as the law on civil service, the law on the judiciary and the law on police authorities, in order to specify rights and obligations.

\section{Bulgaria}

The Bulgarian authorities repealed the provision of art. 307 of the criminal code which provided penal responsibility for provoking bribery. This article was often used for personal revenge and therefore was not efficient in the fight against corruption. At the moment Bulgarian legislation gives no explicit definition of corruption as a criminal act, but it finds its implicit classification in several forms of crimes, legislated in the criminal code. There is a particular provision which enables the centre office to monitor corruption in central and local administration. At the moment the Bulgarian Parliament is debating on the definition of corruption and there seems to be interest also in the extension of the crime of corruption of foreign officials.

\section{PREVENTIVE MEASURES}

If corruption is systematic, it is illusory to think that it can be addressed exclusively by penal repression. Aware of the limits of penal repression, authorities should introduce preventive measures.

There are various ways to prevent corruption. Among the most important are codes of conduct. Some countries of the area, such as Poland, Moldova and Hungary, have introduced codes of conduct to be observed by public officials. Other countries have codes of conduct regulating professions exposed to corruption; among these are Croatia, Slovenia and Lithuania. Bulgaria does not have a code of conduct for public officials, but there are certain requirements for judges, prosecutors and magistrates.

Corruption can also be combated by implementing controls over the financial assets of members of parliament and senior officials. Financial declarations are sometimes voluntary and other times mandatory. Among the states which have introduced mandatory reporting are Slovenia, Lithuania, Ukraine, Estonia and Poland.

Some countries have elaborated special procedures for controlling finances in public administration. Bulgaria has an independent authority controlling these finances, and the same type of authorities function in Croatia, Slovakia, Hungary, Latvia and Poland.

Poland, Hungary, Estonia, Slovakia and Slovenia are among those countries who require the documentation of transactions by public authorities. Particular attention has been focused on the financing of political parties. In fact several countries have enacted specific legislation on this topic, among them Slovenia, Slovakia, Poland, Moldova, Lithuania, Latvia, Hungary, Estonia and Bulgaria.

Civil remedies are also efficient instruments in the fight against bribery; a contract influenced by corruption should be invalid. The enacting of laws concerning the seizure and confiscation of assets related to corruption is another efficient counter-measure.

\section{CO-OPERATION NEEDED}

Since the beginning of the 1990s many countries of the Eastern bloc have been seriously involved in fighting against corruption. New legislative provisions have been enacted or are in the process of being enacted, new criminal codes have come into force, and many innovative issues are being considered. The major concern regards the implementation of the measures taken, because laws must be translated into concrete behaviour which needs organisational and cultural effort.

\section{on the internet}

http://www.un.org/ecosocdev/geninfo/crime/dpi1644e.htm

In depth discussion on the UN's position in relation to transnational crime can be found at the above address

When corruption takes the form of an international crime, national legal instruments are not able efficiently to combat this phenomenon. An effective campaign against corruption in international trade may be undertaken only by means of the internationalisation of legal instruments. Therefore the authorities of the countries of Central and Eastern Europe should improve the efficiency and effectiveness of international co-operation by promoting bilateral and multilateral agreements, encouraging co-operation between criminal justice agencies and other authorities, and implementing the recommendations of international organisations.

Corruption is a phenomenon found on the axes of morality and law. The solution most frequently tendered in the fight against corruption is the improvement of the legal system; yet a state of law is not enough. Governments should consider developing educational programmes to create a culture of public morality and legality in order to make clear to the public that corruption produces an increase in economic and social cost to be paid by the community. Another goal to achieve in the fight against corruption is the establishment of channels for complaints and for voluntary reporting of corruption cases and the elaboration of protection programmes for 'whistle blowers'.

\section{Joseph Masè \\ Assistant Researcher at Transcrime}

This article is based on research carried out at Transcrime, Research Group on Transnational Crime, School of Law, University of Trento, Italy. 